\title{
PEMANFAATAN DATA WAREHOUSE PADA INSTITUSI PEMERINTAHAN
}

\author{
Rudy \\ Information Systems Department, School of Information Systems, Binus University \\ Jln. K.H. Syahdan No. 9, Palmerah, Jakarta Barat 11480 \\ rudy@binus.edu
}

\begin{abstract}
Data warehouse has a very important role in assisting of decision making, where the data warehouse became the core. Data in the data warehouse provide valuable information for its users. By using data warehouse, governance institutions can conduct data analyzes in order to build new strategies to make benefits for all stakeholders. This paper discusses about the design of data warehouse in Balai Besar Riset Sosial Ekonomi dan Kelautan. Data warehouse design using dimensional model approach introduced by Kimball. The information required by management at Balai Besar Riset Sosial Ekonimi dan Kelautan are divided into three groups: income, consumption and commerce. With the data warehouse organizations can easily perform analyses and generate reports, which can be viewed from various scopes, including time, region, fishermen and fisheries.
\end{abstract}

Keywords: data warehouse, dimensional model, fisheries, decision support system

\begin{abstract}
ABSTRAK
Data warehouse memiliki peranan yang sangat penting dalam membantu pihak pemakai dalam membuat suatu keputusan, di mana data warehouse menjadi intinya. Data-data yang terdapat dalam data warehouse dapat memberikan informasi yang berharga bagi penggunanya. Dengan pemanfaatan data warehouse institusi pemerintahan dapat melakukan analisis-analisis terhadap data yang dimiliki guna membangun strategi baru yang bermanfaat bagi para pemangku kepentingan. Artikel ini membahas perancangan data warehouse pada Balai Besar Riset dan Sosial Ekonomi Kelautan dan Perikanan. Perancangan data warehouse menggunakan pendekatan model dimensional yang dikenalkan oleh Kimball. Informasi yang dibutuhkan oleh manajemen pada institusi tersebut dibagi ke dalam tiga kelompok, yaitu pendapatan, konsumsi dan usaha. Dengan adanya data warehouse ini organisasi dapat dengan mudah melakukan analisis dan pembuatan laporan, yang dapat dilihat dari berbagai dimensi, di antaranya dimensi waktu, wilayah, nelayan dan perikanan.
\end{abstract}

Kata kunci: data warehouse, model dimensional, kelautan dan perikanan, sistem penunjang keputusan 


\section{PENDAHULUAN}

Sistem pendukung keputusan (SPK) adalah salah satu dari sistem informasi manajemen yang tujuan utamanya adalah untuk mendukung pengambilan keputusan yang dilakukan oleh manajemen. Kekuatan SPK terletak dalam mendukung pengambilan keputusan dalam situasi di mana dua hal perlu diperhatikan, yaitu penilaian manusia dan kekuatan dari komputer. Fungsi Utama SPK dapat mendukung perencanaan yang bersifat strategik, taktikal dan operasional. Dirancang secara tepat dan terintegrasi, SPK menjadi alat dukungan yang sangat kuat yang dapat meningkatkan produktivitas para professional dari segala level dalam semua departemen (Raman \& Tewari, 2011). Dengan adanya SPK ini manajemen suatu organisasi dapat melakukan analisis terhadap kondisi yang ada untuk menentukan langkah-langkah ke depan untuk organisasi.

Idealnya pengambilan keputusan organisasi dimulai dengan analisis yang mendalam dari informasi manajemen yang tersedia. Pengambil keputusan kemudian menggunakan informasi untuk mempertimbangkan alternatif, menganalisis pilihan dan mengantisipasi implikasi dan proyeksi hasil didalam konteks organisasi dan lingkungannya (Guan, Nunez, \& Welsh, 2002). Untuk mendukung pengambilan keputusan di dalam sebelumnya dilakukan analisis, organisasi tidak cukup hanya menggunakan Online Transaction Processing (OLTP) atau basis data operasional. Hal ini karena OLTP tidak cocok untuk mendukung keputusan, OLTP dirancang untuk mendukung transaksi yang bersifat jangka waktu pendek. Tipe data ini hanya mencerminkan kondisi saat ini dari sistem dan jarang menyimpan data-data historis yang penting dalam melakukan perencanaan (Guan, Nuzez, \& Welsh, 2002).

Dalam melakukan perencanaan pihak manajemen membutuhkan informasi yang tidak hanya informasi pada saat ini saja tetapi membutuhkan informasi yang memiliki rentang waktu yang panjang, yang tersimpan dalam historical data dan tersimpan di dalam data warehouse. Data warehouse tidak hanya digunakan dalam melakukan loading, integrasi, dan menyimpan data dalam jumlah besar, namun juga berpotensi untuk mendapatkan insight baru dari sebaran data, dan memungkinkan untuk memberikan pelaporan dan jawaban dari pertanyaan pengguna yang bersifat ad hoc secara cepat dan lebih baik (Williams \& Williams, 2007,p.29). Data warehouse menyediakan solusi untuk memenuhi kebutuhan informasi dari pengambil keputusan institusional. (Guan, Nunez \& Welsh, 2002).

Balai Besar Riset Sosial Ekonomi Kelautan dan Perikanan merupakan bagian dari Kementerian Kelautan dan Perikanan, yang bertugas mendata kehidupan para nelayan mengenai pendapatan, konsumsi, dan usaha. Kegiatan tersebut dinamakan Panel Perikanan Nasional (PANELKANAS) yang meliputi Perikanan Tangkap Laut, Perikanan Tangkap Perairan Umum dan Daratan, Perikanan Budidaya, dan Produk Kelautan. Kepala peneliti, Kepala Pelayanan Teknis, Kepala Teknologi Informasi, Direktorat Jendral Kementrian Kelautan Perikanan dan Pemerintah daerah memerlukan suatu laporan untuk melihat tren kehidupan nelayan, dan juga berkaitan dengan pengambilan keputusan untuk menentukan arah penelitian dan kebijakan kelautan dan perikanan. Laporan dan analisis yang dibutuhkan oleh pihak-pihak yang terkait di atas, dapat dipenuhi dengan menyiapkan data warehouse yang berisikan data-data histori dan informasi yang dibutuhkan.

Aplikasi yang digunakan saat ini oleh Balai Besar Riset Sosial Ekonomi Kelautan dan Perikanan (BBRSEKP) adalah Panel Perikanan Nasional (PANELKANAS) belum dapat memenuhi kebutuhan laporan. Hal ini disebabkan oleh beberapa faktor di antaranya: basis data yang tersebar dibeberapa kantor wilayah dan kebutuhan laporan oleh pihak pimpinan/manajemen yang belum dapat dipenuhi oleh basis data operasional, seperti membandingkan data berdasarkan waktu dan wilayah. 


\section{METODE}

Adapun metodologi yang diterapkan dalam studi ini yaitu: (1) mengumpulkan data dan informasi melalui wawancara dan observasi terhadap sistem informasi yang saat ini berjalan serta basis data operasional yang digunakan; (2) melakukan analisis terhadap kebutuhan informasi yang akan disajikan kepada pihak manajemen; (3) melakukan perancangan data warehouse dengan menggunakan pendekatan dimensional model yang dikenalkan oleh Kimball (Kimball's Business Dimensional Lifecycle). Serta melakukan perancangan dashboard untuk menampilkan informasi yang dihasilkan oleh data warehouse.

\section{HASIL DAN PEMBAHASAN}

\section{Analisis Kebutuhan Informasi}

Kebutuhan informasi pada BBRSEKP terbagi ke dalam tiga kelompok. Pertama adalah pendapatan, yaitu: total pendapatan rumah tangga nelayan, struktur pendapatan rumah tangga nelayan, rata-rata pendapatan rumah tangga nelayan, dan perbandingan pendapatan rumah tangga nelayan berdasarkan pendapatan utama dan pendapatan sampingan. Kedua adalah konsumsi: total konsumsi rumah tangga nelayan, rata-rata konsumsi rumah tangga nelayan, nilai konsumsi rumah tangga nelayan berdasarkan jenis konsumsi dan pengeluaran, perbandingan konsumsi rumah tangga nelayan berdasarkan konsumsi pangan dan konsumsi non pangan, dan jumlah anggota rumah tangga dan konsumsi bahan makanan. Kelompok ketiga adalah usaha: usaha musim penangkapan, kebutuhan investasi dan keragaman usaha perikanan, struktur investasi usaha penangkapan perikanan, struktur biaya dan analisis usaha perikanan, struktur rata-rata biaya usaha penangkapan perikanan, kalender penangkapan dan rata-rata jumlah kegiatan penangkapan usaha perikanan, biaya operasional usaha penangkapan perikanan, perbandingan usaha rumah tangga nelayan perikanan berdasarkan investasi, biaya tetap, biaya variabel, penerimaan, dan keuntungan, jenis usaha penangkapan nelayan, perhitungan keuntungan usaha pada perikanan, dan jenis aset perikanan budidaya.

\section{Data Warehouse}

Data warehouse memiliki beberapa tujuan, diantaranya adalah membuat informasi yang dimiliki organisasi dapat dengan mudah diakses, menyajikan informasi yang dimiliki organisasi secara konsisten, dan memberikan landasan yang kuat dalam meningkatkan pembuatan keputusan (Kimball \& Ross ,2002, p3-4). Data warehouse memiliki beberapa karakteristik utama yaitu subject-oriented, time-variant, non-volatile, dan integrated. Definisi di atas dapat dijelaskan sebagai berikut:

\section{Subject-Oriented}

Data dalam data warehouse diatur dan dioptimalkan untuk memberikan jawaban atas pertanyaan yang diajukan oleh beberapa area fungsional dalam organisasi. Oleh karenanya, data warehouse berisikan data yang terorganisir dan dirangkum berdasarkan subyek. Dalam kasus ini subyek adalah Nelayan, Wilayah dan Jenis Budidaya.

\section{Time-Variant}

Dalam sistem Online Transaction Processing (OLTP) berfokus kepada transaksi yang terjadi pada saat ini, sedangkan data dalam data warehouse berisikan data dari rentang waktu yang panjang, 
dan berisikan data-data yang terjadi pada waktu tertentu. Data warehouse BBRSEKP yang dirancang akan berisikan data dari tahun 2007-2011.

\section{Non-Volatile}

Data yang berada dalam data warehouse tidak pernah dihapus dan penambahan data terbaru selalu dilakukan untuk kebutuhan analisis maupun pelaporan, oleh karenanya data dalam data warehouse selalu bertambah. Ketika data operasional dipindahkan ke dalam data warehouse berarti data warehouse berisikan data histori dari perusahaan. Pada data warehouse BBRSEKP setelah memindahkan data operasional dari tahun 2007-2011, akan ditambahkan data-data pada tahun sesudah 2011, dan data yang telah masuk ke dalam data warehouse BBRSEKP tetap disimpan.

\section{Integrated}

Data warehouse adalah terpusat yang berisikan konsilidasi dari beberapa basis data yang tersebar di suatu organisasi. Data warehouse selain berisikan gabungan dari beberapa basis data, berisikan juga konsilidasi data yang terdiri dari beberapa "format" yang berbeda. Pada data warehouse BBRSEKP berisikan konsilidasi dari basis data produk laut, tangkap laut, umum daratan dan budidaya.

Gambar 1 merupakan arsitektur data warehouse yang diusulkan pada BBRSEKP, basis data produk laut, tangkap laut, umum daratan dan budidaya yang merupakan OLTP (basis data transaksional). Tahap pertama akan dilakukan ekstraksi dari OLTP ke dalam staging area, yaitu memindahkan data-data dari OLTP ke dalam staging area. Tahap kedua, data-data yang telah dipindahkan ini akan dilakukan transformasi. Proses yang dilakukan diantaranya adalah standarisasi tipe data, pembersihan data, derivasi, denormalisasi, aggregasi, audit informasi dan konversi "null".Tahap ketiga adalah mengisi data warehouse dengan data-data yang telah ditransformasi (Loshin, 2003, p.148).

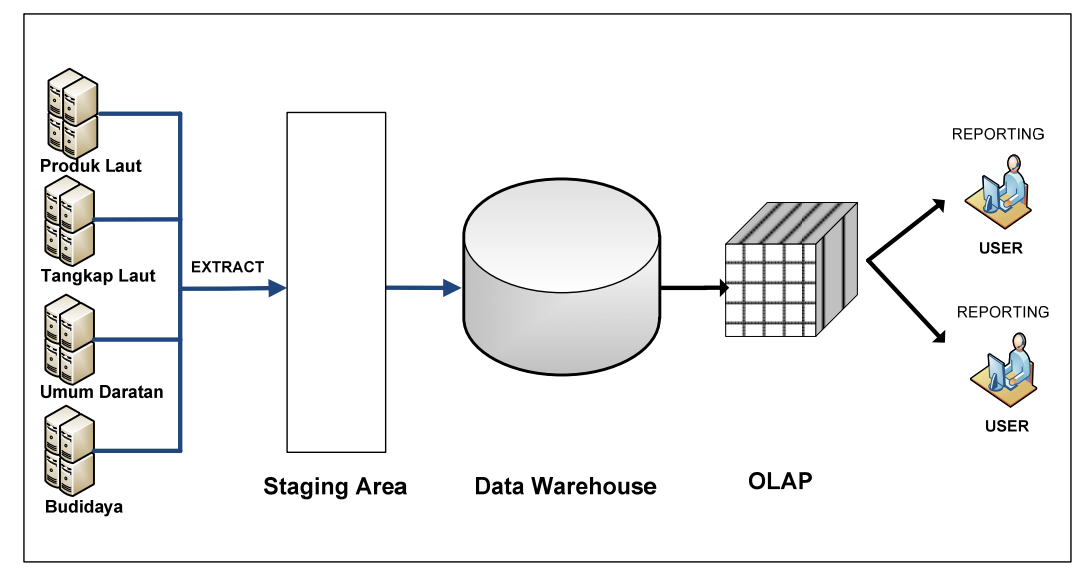

Gambar 1. Arsitektur data warehouse.

\section{Pembangunan Data Warehouse (Kimball's Business Dimensional Lifecycle)}

\section{Menentukan Proses Bisnis}

Proses bisnis mengacu kepada subyek data mart tertentu. (Connolly \& Begg, 2011, p.1231). Pada BBRSEKP terdapat banyak peneliti memiliki keahlian di bidang sosial ekonomi yang ditugaskan mengumpulkan data-data kondisi sosial ekonomi secara rutin (monitoring) di empat sektor kelautan 
dan perikanan. Kondisi pendapatan yang diukur meliputi pendapatan keluarga nelayan, pendapatan nelayan atas aset yang dimiliki, dan pendapatan hasil menyewakan alat usaha. Kondisi konsumsi keluarga nelayan yang diukur meliputi konsumsi pangan dan non pangan, konsumsi pangan meliputi konsumsi makanan dan pengeluaran konsumsi ikan sehari-hari, sedangkan konsumsi non pangan meliputi biaya pendidikan, biaya perawatan rumah dan perlengkapan dapur. Kondisi usaha nelayan yang diukur meliputi usaha perikanan dan usaha non perikanan yang dilakukan oleh nelayan, serta data sumber modal usaha yang didapat dari para nelayan. Gambar 2 di bawah ini memperlihatkan Entity Relationship Diagram (ERD)pada sistem yang sedang berjalan.

\section{Menentukan Grain}

Memilih tingkatan dari "grains" ditentukan dengan menemukan keseimbangan antara memenuhi kebutuhan bisnis dan yang mungkin diberikan oleh sumber data (Connolly \& Begg, 2011, p.1233). Pada BBRSEKP terdapat tiga grains, yaitu: (1) pendapatan - analisis pada pendapatan meliputi: total pendapatan keluarga nelayan, rata-rata pendapatan keluarga nelayan per sumber pendapatan dan per jenis pekerjaan, total pendapatan keluarga per alat tangkap, perbandingan pendapatan nelayan per pendapatan utama dan per pendapatan sampingan, total pendapatan nelayan pper kepemilikan usaha, jumlah pendapatan sewa, total pendapatan sewa per jenis aset dan per pola pendapatan; (2) konsumsi - analisis pada konsumsi meliputi, total konsumsi rumah tangga perikanan per jenis konsumsi dan wilayah, rata-rata konsumsi rumah tangga nelayan, total konsumsi rumah tangga nelayan per jenis konsumsi dan per jenis pengeluaran, perbandingan konsumsi rumah tangga nelayan per konsumsi pangan dan non pangan, total konsumsi dan pengeluaran per skala usaha, jumlah pengeluaran konsumsi nelayan dan total konsumsi rumah tangga nelayan per status pengelolaan; (3) usaha - analisis pada usaha meliputi, tipe usaha yang memerlukan investasi, struktur biaya usaha nelayan perikanan, rata-rata biaya usaha penangkapan usaha perikanan, total biaya usaha operasional nelayan perikanan, perbandingan usaha nelayan perikanan per struktur biaya, total keuntungan usaha nelayan perikanan, jumlah jenis aset, total nilai jenis aset nelayan perikanan, dan rata-rata nilai jenis asset nelayan perikanan.

\section{Memilih Dimensi}

Dimensi menentukan konteks yang akan ditanyakan mengenai fakta-fakta pada tabel fakta (Connolly \& Begg, 2011, p.1233). Untuk data warehouse pada BBRSEKP yang dibangun, berikut dimensi-dimensi yang dibutuhkan (Tabel 1).

Tabel 1

Tabel Dimensi dan Grain

\begin{tabular}{|c|c|c|c|}
\hline Dimensi & Pendapatan & Konsumsi & Usaha \\
\hline Waktu & $\mathrm{x}$ & $\mathrm{x}$ & $\mathrm{x}$ \\
\hline Nelayan & $\mathrm{x}$ & $\mathrm{x}$ & $\mathrm{x}$ \\
\hline Perikanan & $\mathrm{x}$ & $\mathrm{x}$ & $\mathrm{x}$ \\
\hline Wilayah & $\mathrm{x}$ & $\mathrm{x}$ & $\mathrm{x}$ \\
\hline Pekerjaan & $\mathrm{x}$ & & $\mathrm{x}$ \\
\hline Referensi & $\mathrm{x}$ & $\mathrm{x}$ & $\mathrm{x}$ \\
\hline Keluarga & $\mathrm{x}$ & & \\
\hline Aset & $\mathrm{x}$ & & $\mathrm{x}$ \\
\hline Bahan Konsumsi & & $\mathrm{x}$ & \\
\hline Biaya & & & $\mathrm{x}$ \\
\hline Lembaga & $\mathrm{x}$ & & \\
\hline Pengeluaran & & & $\mathrm{x}$ \\
\hline Usaha Pengolahan & & & $\mathrm{x}$ \\
\hline
\end{tabular}




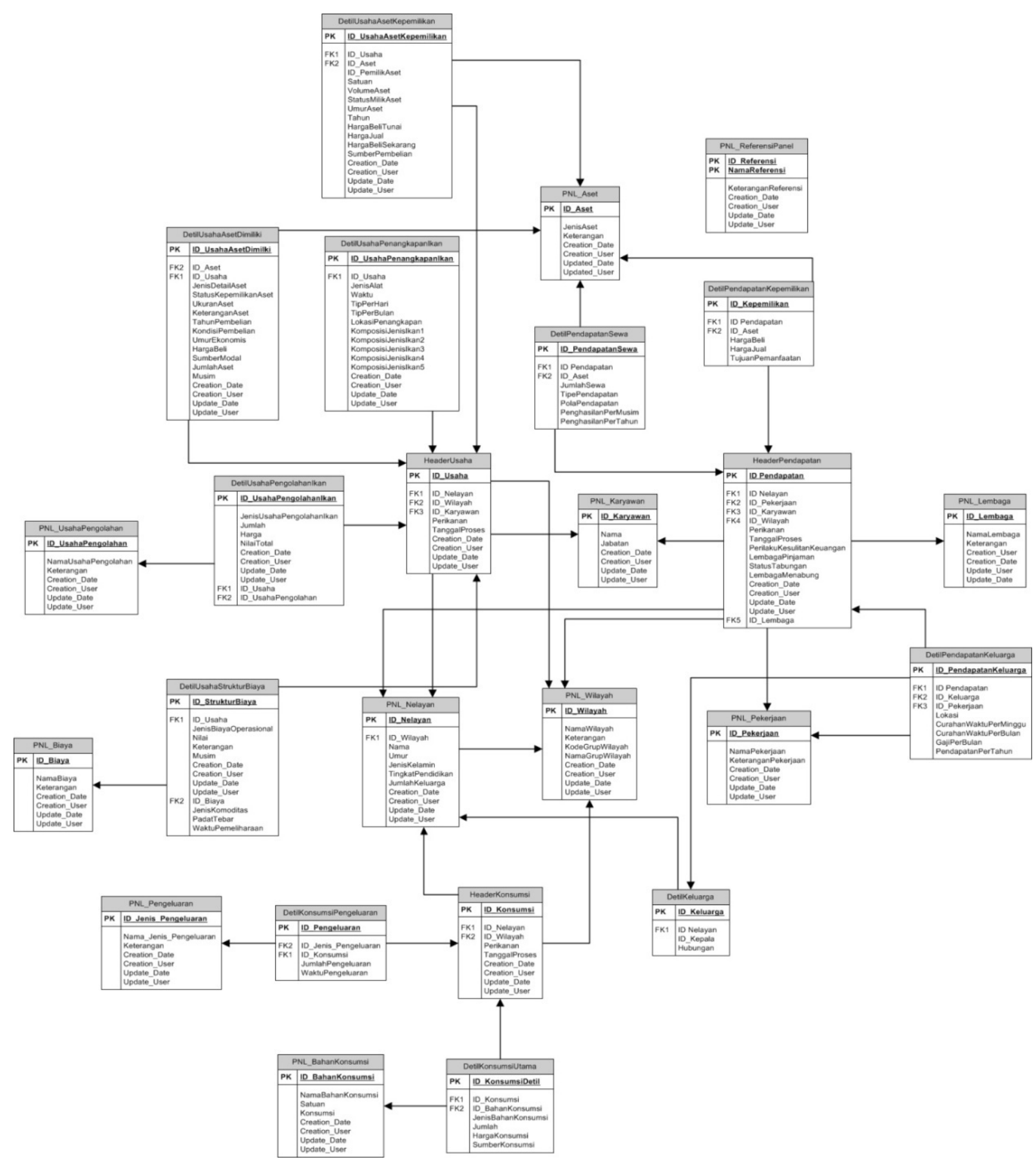

Gambar 2. ERD pada sistem berjalan.

\section{Identifikasi Fakta}

Grain dari tabel fakta menentukan fakta-fakta yang dapat digunakan dalam model dimensional. Semua fakta harus dinyatakan dalam tingkatan yang ditentukan oleh grain (Connolly \& Begg, 2011, p. 1235). Berikut adalah fakta-fakta yang digunakan dalam data warehouse BBRSEKP: (1) fakta konsumsi pengeluaran berisi total konsumsi pengeluaran; (2) fakta konsumsi utama berisi jumlah bahan konsumsi, total konsumsi, dan rata-rata konsumsi; (3) fakta pendapatan keluarga berisi total pendapatan keluarga, dan rata-rata pendapatan keluarga; (4) fakta pendapatan sewa berisi jumlah 
sewa dan total pendapatan sewa; (5) fakta pendapatan kepemilikan berisi total pendapatan harga beli, total pendapatan harga jual, dan total pendapatan kepemilikan; (6) fakta usaha aset dimiliki berisi total harga beli rata-rata usaha aset dan total usaha asset; (7) fakta usaha aset kepemilikan berisi total harga beli, total harga jual, dan total harga beli sekarang; (8) fakta usaha pengolahan ikan berisi jumlah pengolahan ikan, dan total pengolahan ikan; (9) fakta usaha struktur biaya berisi total struktur biaya dan jumlah struktur biaya; (10) fakta usaha penangkapan ikan berisi jumlah penangkapan ikan.

\section{Skema Bintang}

Skema bintang adalah model data dimensional yang memiliki tabel fakta di tengah, dan dikelilingi oleh tabel dimensional denormalisasi. (Connolly \& Begg, 2011, p. 1227). Gambar 3 merupakan skema bintang untuk fakta konsumsi utama di mana pada fakta ini informasi yang dihasilkan adalah jumlah konsumsi utama dan nilai harga konsumsi utama yang dapat dilihat berdasarkan nelayan, perikanan, bahan komsumsi, wilayah, referensi dan waktu. Kemudian Gambar 4 merupakan skema bintang untuk fakta pendapatan keluarga, informasi yang dapat dihasilkan adalah jumlah waktu kerja dan nilai pendapatan, di mana informasi ini dapat dilihat berdasarkan dimensi referensi, lembaga, nelayan, pekerjaan, perikanan, waktu, wilayah dan keluarga. Selanjutnya Gambar 5 merupakan skema bintang untuk fakta usaha aset dimiliki, informasi yang dihasilkan adalah jumlah aset, ukuran aset, umur ekonomis dan nilai harga beli yang dapat dilihat berdasarkan dimensi perikanan, referensi, wilayah, pekerjaan, aset, nelayan, dan waktu.

\section{Aplikasi Dashboard}

Untuk menampilkan data warehouse yang telah dirancang digunakan aplikasi dashboard dari datamicron (Gambar 6-8). Pada Gambar 6, dapat dilihat tampilan dashboard untuk pendapatan berdasarkan wilayah (menggunakan peta), pada tombol berwarna hijau dan biru dapat diklik untuk mendapatkan informasi lebih detail seperti terlihat pada Gambar 7. Pada Gambar 8, dapat dilihat tampilan laporan dalam bentuk pivot, disini pemakai dapat memilih atau menentukan dimensi yang akan ditampilkan dalam laporan.

\section{PENUTUP}

Data warehouse dapat membantu manajemen dalam melakukan analisis terhadap kondisi yang ada dalam rentang waktu yang panjang, karena data warehouse dapat menampung data-data historis, sehingga manajemen dapat melihat tren yang terjadi dari waktu ke waktu. Dengan memanfaatkan aplikasi dashboard, manajemen dapat dengan mudah melihat kondisi yang ada pada organisasi karena disajikan dalam bentuk grafikal. Sedangkan laporan yang disajikan dari data warehouse menampilkan informasi yang dapat dilihat secara rinci berdasarkan beberapa dimensi yang dibutuhkan.

\section{DAFTAR PUSTAKA}

Connolly, Thomas \& Begg, Carolyn. (2010). Database Systems: A Practical Approach to Design, Implementation, and Management (fifth edition). Boston: Addison-Wesley.

Guan, J., Nunez, W., \& Welsh, J.F. (2002). Institutional strategy and information support: the role of data warehousing in higher education. Campus-Wide Information Systems, 19 (5), ISSN 10650741. 
Kimball, Ralph \& Ross, Margy. (2002). The Data warehouse Toolkit (second edition). Indianapolis: Jon Wiley \& Sons.

Loshin, David. (2003). Business Intelligence: the Savvy Manager's Guide. San Francisco: Morgan Kaufmann.

Raman, V. V. R., \& Tewari, Veena. (2011). Decision support system and managerial decision making. International Journal of Knowledge and Research in Management \& E-Commerce 1(1).

Williams, Steve \& Williams, Nancy. (2007). The Profit Impact of Business Intelligence. San Francisco: Morgan Kaufmann.

\section{APPENDIX}

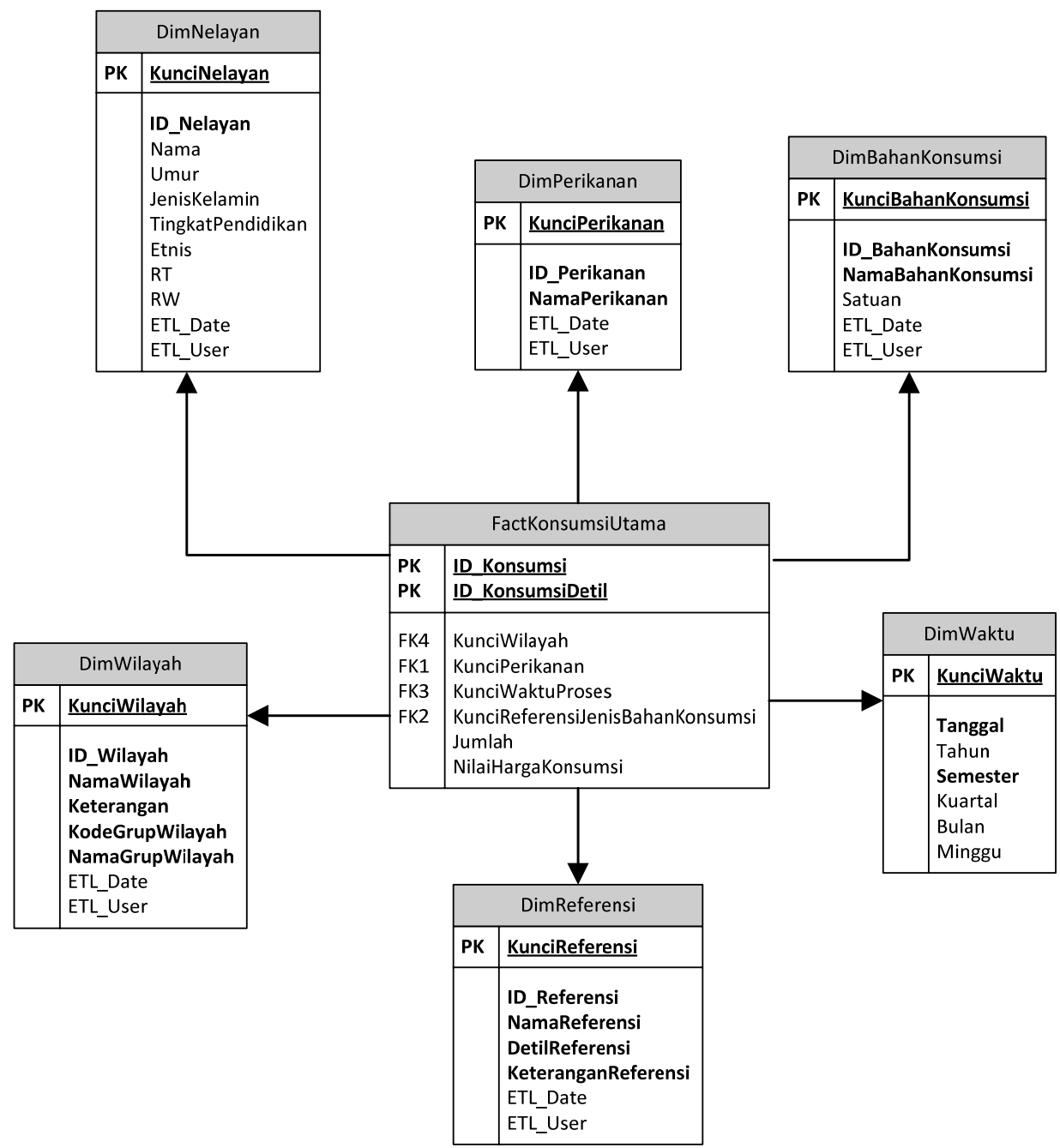

Gambar 3. Gambar skema bintang konsumsi utama. 


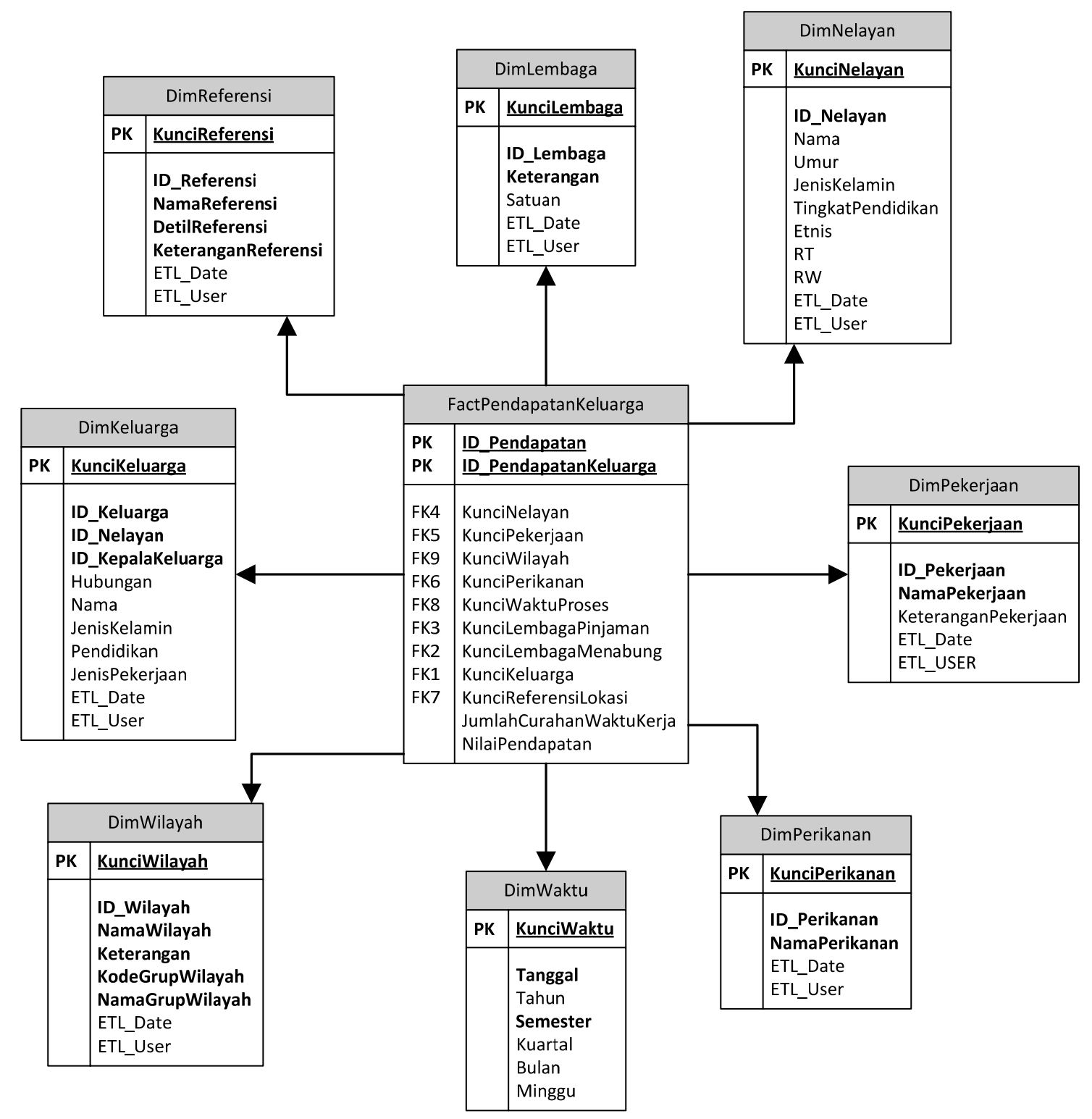

Gambar 4. Gambar skema bintang pendapatan keluarga. 


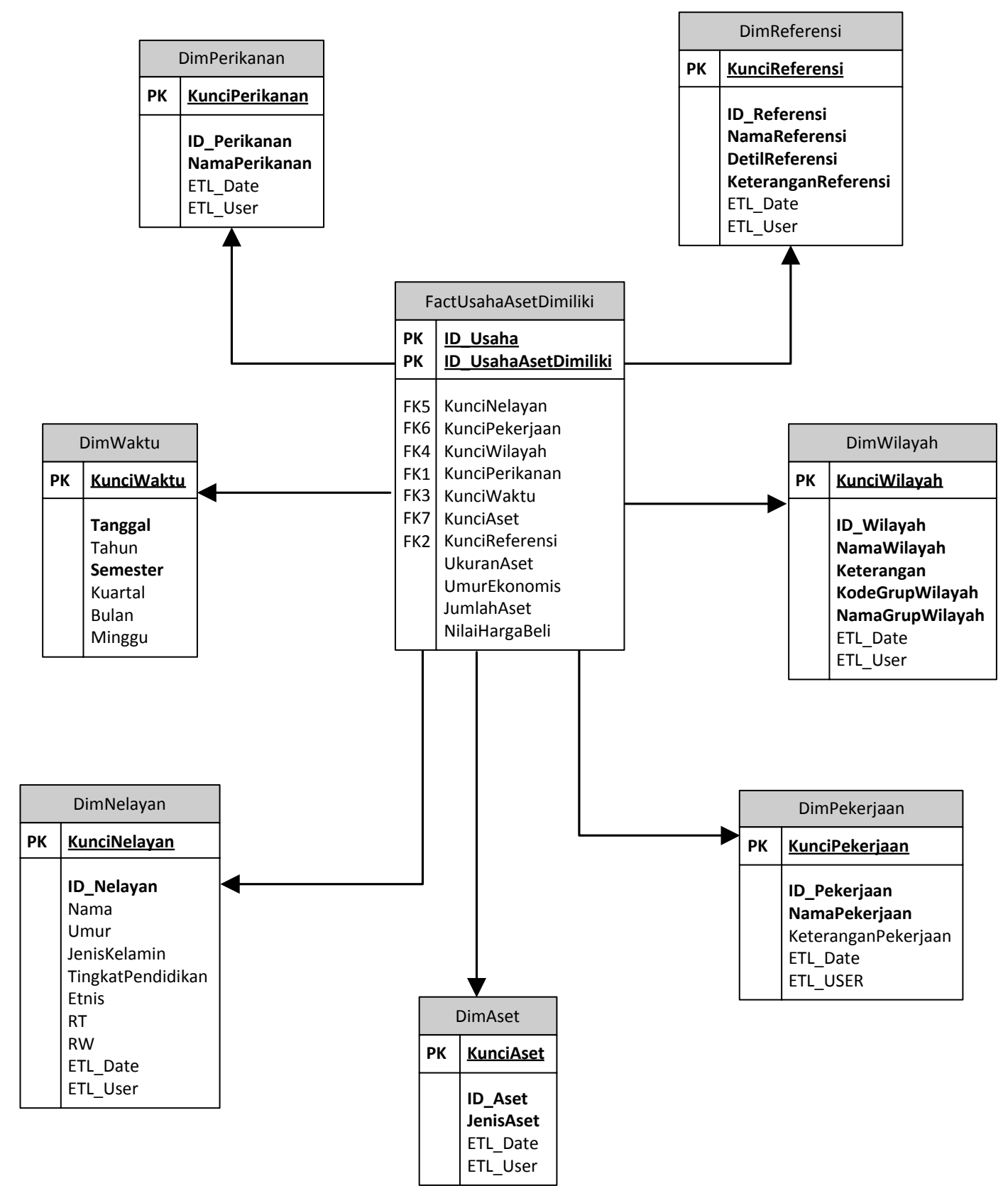

Gambar 5. Gambar skema bintang usaha aset yang dimiliki. 


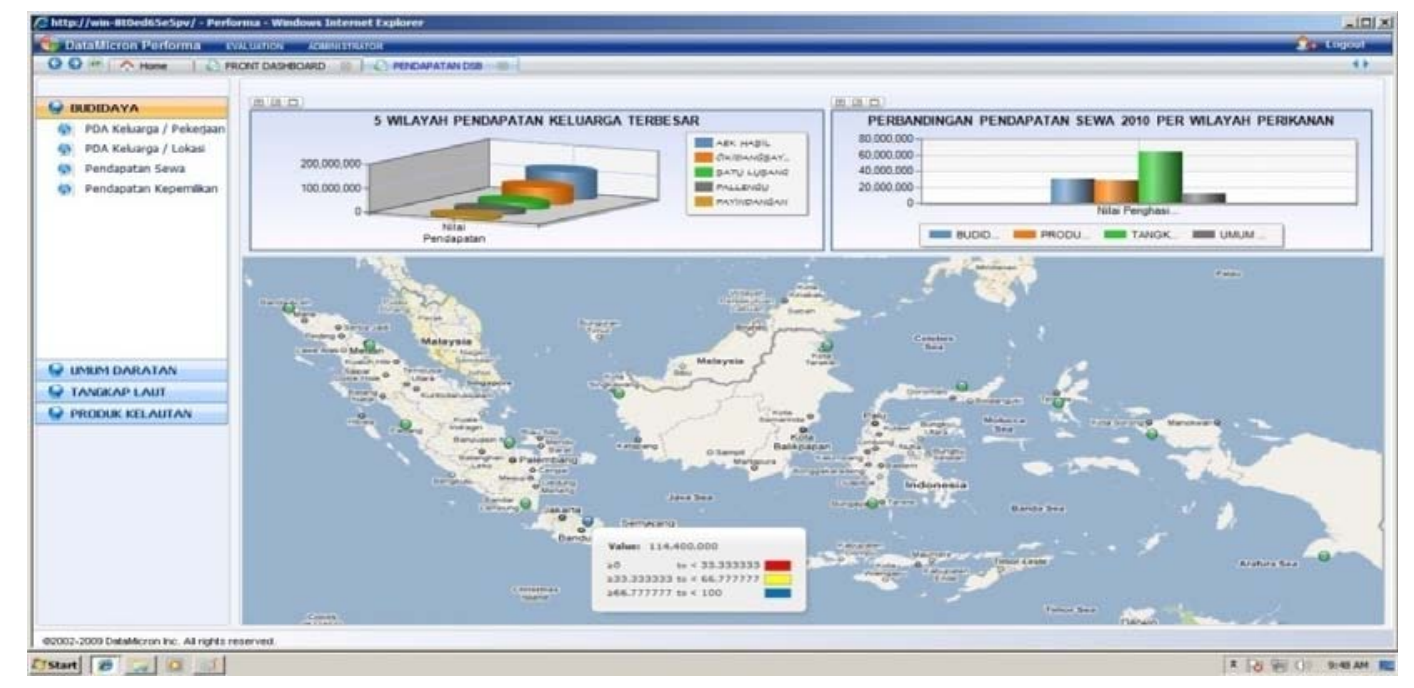

Gambar 6. Tampilan dashboard pendapatan.

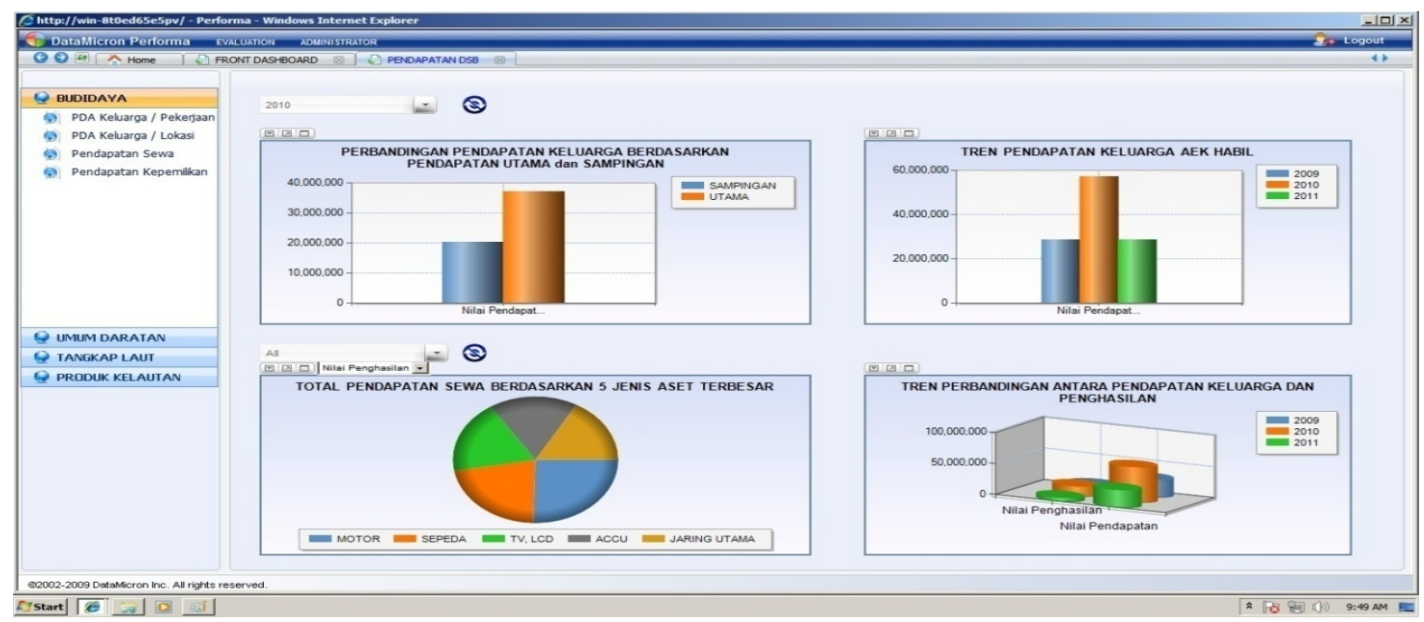

Gambar 7. Tampilan dashboard pendapatan detil.

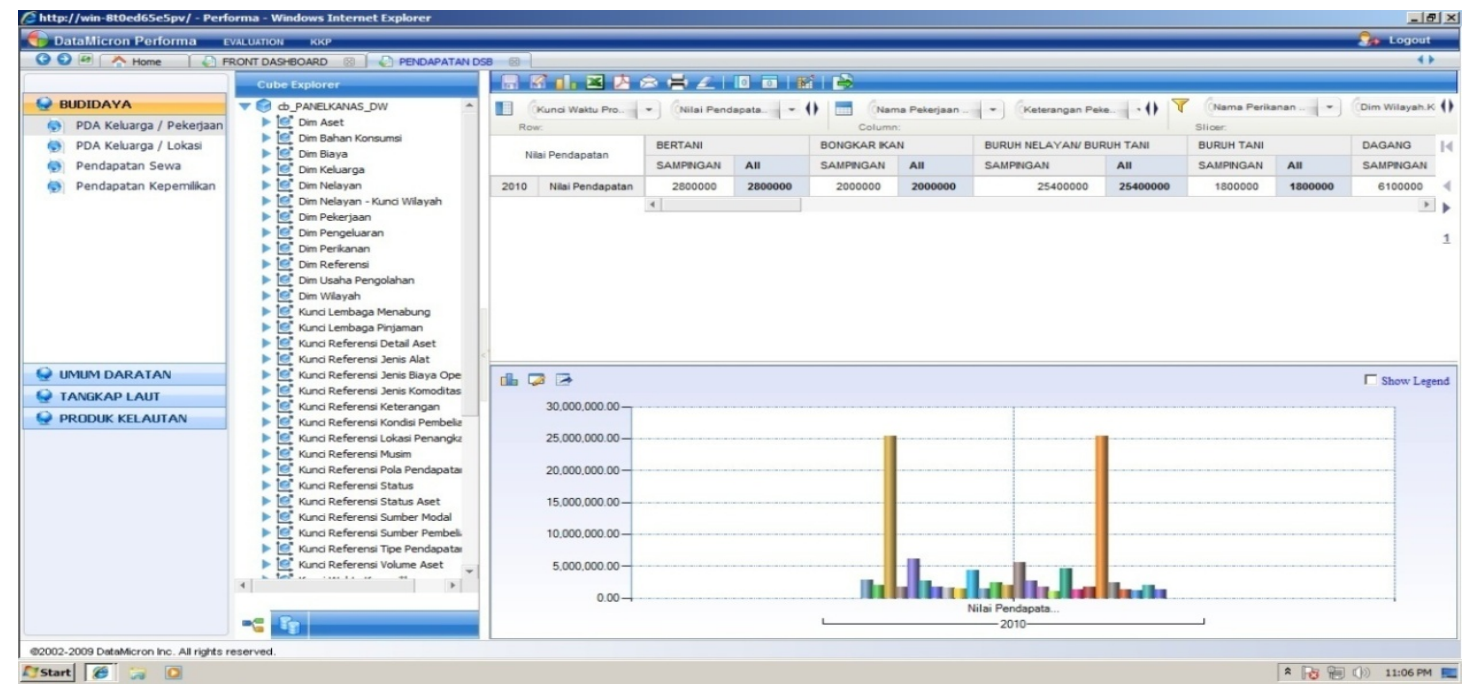

Gambar 8. Tampilan laporan. 